\title{
Integration of multi-criteria and nearest neighbour analysis with kernel density functions for improving sinkhole susceptibility models: the case study of Enemonzo (NE Italy)
}

\author{
Chiara Calligaris $^{1}$, Stefano Devoto ${ }^{1}$, Jorge P. Galve ${ }^{2 *}$, Luca Zini ${ }^{1}$, and José V. Pérez-Peña ${ }^{2}$
}

${ }^{1}$ Dipartimento di Matematica e Geoscienze, Università degli Studi di Trieste, Piazzale Europa, 1, 34127 Trieste, Italy

${ }^{2}$ Departamento de Geodinámica, Universidad de Granada, Av. del Hospicio, s/n, 18010 Granada, Spain

\begin{abstract}
The significance of intra-mountain valleys to infrastructure and human settlements and the need to mitigate the geo-hazard affecting these assets are fundamental to the economy of Italian alpine regions. Therefore, there is a real need to recognize and assess possible geohazards affecting them. This study proposes the use of GIS-based analyses to construct a sinkhole susceptibility model based on conditioning factors such as land use, geomorphology, thickness of shallow deposits, distance to drainage network and distance to faults. Thirtytwo models, applied to a test site (Enemonzo municipality, NE Italy), were produced using a method based on the Likelihood Ratio $(\lambda)$ function, nine with only one variable and 23 applying different combinations. The sinkhole susceptibility model with the best forecast performance, with an Area Under the Prediction Rate Curve (AUPRC) of 0.88 , was that combining the following parameters: Nearest Sinkhole Distance (NSD), land use and thickness of the surficial deposits. The introduction of NSD as a continuous variable in the computation represents an important upgrade in the prediction capability of the model. Additionally, the model was refined using a kernel density estimation that produced a significant improvement in the forecast performance.
\end{abstract}

Keywords: evaporite karst, sinkhole, susceptibility, nearest neighbour, prediction-rate curves

Received 4 December 2016; Revised 25 April 2017; Accepted 28 April 2017

Citation: $\quad$ Calligaris C., Devoto S., Galve J.P., Zini L. and Pérez-Peña, J.V., 2017. Integration of multicriteria and nearest neighbour analysis with kernel density functions for improving sinkhole susceptibility models: the case study of Enemonzo (NE Italy). International Journal of Speleology, 46 (2), 191-204. Tampa, FL (USA) ISSN 0392-6672 https://doi.org/10.5038/1827-806X.46.2.2099

\section{INTRODUCTION}

Several regions of Europe are affected by groundsubsidence phenomena caused by the presence of highly soluble evaporite rocks. These phenomena represent a severe geo-hazard for many European countries such as France (Thierry et al., 2009), Germany (Dahm et al., 2010), Lithuania (Paukstys et al., 1999), Russia (Koutepov et al., 2008), Spain (Gutiérrez et al., 2008), the United Kingdom (Cooper, 1995; Cooper et al., 2011) and Albania (Parise et al., 2004). Italy is also affected by this type of geohazard (Nisio et al., 2007; Caramanna et al., 2008; Di Maggio et al., 2010; Iovine et al., 2010; Caporale et al., 2013; Parise \& Vennari, 2013), and the results of recent investigations have shown that the Friuli Venezia Giulia Region (hereafter noted as FVG) is one of the most affected areas of northern Italy (Zini et al., 2015a). Karst areas in FVG are very common (Fabbri et al., 2013; Zini et al., 2014, 2015b, Calligaris et al., 2017a), but only $1 \%$ of the karstifiable lithologies are represented by evaporites. These crop out along the Tagliamento River Valley and along a northern alignment, near the villages of Ovaro (Calligaris et al., 2016), Prato Carnico, Sauris and Ligosullo. The Upper Tagliamento Valley is affected by hundreds of sinkholes, which represent a severe threat to human facilities such as buildings and roads. Here, the combination of an intensively karstified evaporite bedrock, the presence of regional faults, the high amount of annual rainfall $(1600-2000 \mathrm{~mm} / \mathrm{y})$ and large fluctuations of the water table (greater than 10 $\mathrm{m})$ seem to be responsible for the above-mentioned sinkholes. The most notable phenomena are located in Quinis, a hamlet of the Municipality of Enemonzo, where severe damage has been reported since the end of the 1800s (Marinelli, 1898; Gortani, 1965; Zini et al., 2015a).

As karst regions with a high density of sinkholes are a threat to buildings and infrastructure, they 
have been studied through the development of susceptibility maps, obtained by using deterministic, heuristic and probabilistic/statistical methods. Deterministic techniques are based on physicallybased models developed using numerical methods. Heuristic models apply rules defined using expert criteria for determining if an area can be considered a sinkhole-prone area. Probabilistic and statistical methods quantitatively analyze the most important factors that characterize the geological features of the sinkhole-prone areas. Galve et al. (2009a) explained in detail the differences between these techniques and carried out a complete review of the different types of sinkhole susceptibility maps. Table 1 lists the publications in the international scientific literature that describe different methods used for the analysis of sinkhole susceptibility in a variety of geological scenarios.

The methodology used in this paper to build a sinkhole susceptibility map belongs to the probabilistic methods, which do not require the often difficult and expensive information of the deterministic methods. Furthermore, probabilistic methods are more objective than heuristic calculations and provide better results than the other techniques, especially in the analysis of geomorphic processes at the medium and regional scales (e.g., Cervi et al., 2010). Probabilistic and statistical methods have been extensively applied in landslide susceptibility analyses (e.g., Calligaris et al., 2013; Petschko et al., 2014; Piacentini et al., 2015; Steger et al., 2016), but they are not very common in the literature related to karst subsidence sinkholes (see Table 1). The evaporite karst of the Ebro Valley (Spain) is the region where these methods have often been tested (Simón et al., 1991; Soriano \& Simón, 1995; Simón \& Soriano, 2002; Lamelas et al., 2008; Galve et al., 2008, 2009b, 2011), but other authors also used these techniques to produce sinkhole susceptibility maps in other study areas (Hyland, 2005; Yilmaz, 2007; Dai et al., 2008; Doctor et al., 2008; Oh \& Lee, 2010; Nachbaur \& Rohmer, 2011; Doctor \& Doctor, 2012; Papadopoulou-Vrynioti et al., 2013; Pradhan et al., 2014; Cahalan, 2015; D'Angella et al., 2015; Ciotoli et al., 2016; Table 1). The techniques applied by these authors include Logistic Regression, Frequency Ratio, Geographically Weighted Regression, Artificial

Table 1. Main characteristics of the karst areas where susceptibility assessments were developed and the methods used in each one. Method acronyms: SM: Score Method; SA: Stability analysis; LR: Logistic Regression; LRF: Likelihood Ratio Functions; DT: Decision-tree model; GWR: Geographically Weighted Regression; AHP: Analytical Hierarchy Process; FR: Frequency Ratio; EBF: Evidential Belief Function; ANN: Artificial Neural Networks; OLS: Ordinary Least Squares regression; WoE: Weights of Evidence; FL: Fuzzy Logic. Validation type acronyms: CM: Confusion matrix; PRC: Prediction-rate curves; ROC: Receiver Operating Characteristic curves; DF: Degree of Fit.

\begin{tabular}{|c|c|c|c|c|}
\hline Study area & Karst Bedrock & Method & Validation & Reference \\
\hline Algarve (Portugal) & Carbonates & Heuristic (SM) & No & Forth et al., 1999 \\
\hline Crestatx (Spain) & Carbonates & Heuristic & No & García-Moreno \& Mateos, 2011 \\
\hline Loire River (France) & Carbonates & Statistical & No & Samyn et al., 2014 \\
\hline Dzerzhinsk (Russia) & Evaporites & Deterministic (SA) & No & Koutepov et al., 2008 \\
\hline Ebro Valley (Spain) & Evaporites & Statistical & No & Soriano and Simón, 1995 \\
\hline Ebro Valley (Spain) & Evaporites & Statistical (LR) & Yes $(\mathrm{CM})$ & Lamelas et al., 2008 \\
\hline Ebro Valley (Spain) & Evaporites & $\begin{array}{l}\text { Heuristic (SM) and } \\
\text { Probabilistic (LRF) }\end{array}$ & Yes (PRC) & Galve et al., 2009b \\
\hline Fillmore (USA) & Carbonates & Heuristic (DT) & No & Gao and Alexander, 2003 \\
\hline Frederick Valley (USA) & Carbonates & Statistical (GWR) & No & Doctor et al., 2008 \\
\hline Guilin (China) & Carbonates & Heuristic & No & Dai et al., 2008 \\
\hline Hamadan province (Iran) & Carbonates & Heuristic (AHP) & No & Taheri et al., 2015 \\
\hline Jefferson (USA) & Carbonates & Statistical (GWR) & No & Doctor and Doctor, 2012 \\
\hline Karapınar area (Turkey) & Carbonates & Probabilistic (FR) & Yes (ROC) & Ozdemir, 2015 \\
\hline Kinta Valley (Malaysia) & Carbonates & Probabilistic (EBF; FR) & Yes (ROC) & Pradhan et al., 2014 \\
\hline Lazio region (Italy) & Carbonates & Statistical (LR) & Yes (ROC) & Ciotoli et al., 2016 \\
\hline Missouri (USA) & Carbonates & Heuristic (SM) & No & Kaufman, 2008 \\
\hline N Shenandoah Valley (USA) & Carbonates & Statistical & No & Hyland, 2005 \\
\hline Sivas basin (Turkey) & Evaporites & Probabilistic (FR) & Yes (DF) & Yilmaz, 2007 \\
\hline Torre Castiglione (Italy) & Carbonates & Heuristic (DT) & No & Bruno et al., 2008 \\
\hline Tournaisis area (Belgium) & Carbonates & Heuristic & No & Kaufman and Quinif, 2002 \\
\hline Paris (France) & Evaporites & Heuristic-Determ. & No & Thierry et al., 2009 \\
\hline Athens (Greece) & Marbles & Statistical (LR) & No & Papadopoulou-Vrynioti et al., 2013 \\
\hline Tampa (USA) & Carbonates & Heuristic (SM) & No & Zisman, 2001 \\
\hline Kinta Valley (Malaysia) & Carbonates & Heuristic (SM) & No & Al-Kouri et al., 2013 \\
\hline Wuhan city (China) & Carbonates & Heuristic-Determ. & No & Wu et al., 2010 \\
\hline Lesina Marina (Italy) & Evaporites & $\begin{array}{l}\text { Heuristic and Statistical } \\
\text { (LR, ANN) }\end{array}$ & Yes (ROC) & D’Angella et al., 2015 \\
\hline Dougherty County (USA) & Carbonates & Statistical (OLS, GWR) & No & Cahalan, 2015 \\
\hline Samcheok City (Korea) & Carbonates & Probabilistic (WoE) & Yes (ROC) & Oh and Lee, 2010 \\
\hline Arras (France) & Evaporites & Probabilistic (WoE, FL) & No & Nachbaur and Rohmer, 2011 \\
\hline Val d'Orleans (France) & Carbonates & Probabilistic (WoE) & Yes (ROC) & Perrin et al., 2015 \\
\hline
\end{tabular}


Neural Networks and Weights of Evidence. The present paper describes the application of a method based on the Favorability Functions approach (Chung \& Fabbri, 1993), and the Likelihood Ratio (Chung, 2006). Although this technique is a simpler method than the other widely applied statistical methods, it has demonstrated good performances for predicting the occurrences of sinkholes in the Ebro Valley (Spain) (Galve et al., 2008, 2009b, 2011). Moreover, it has been successfully used in landslide susceptibility modeling (e.g., Chung, 2006; Lee \& Pradhan, 2007; Felicísimo et al., 2013). In this paper, the nearest neighbor analysis proposed by Galve et al. (2011) for modelling the sinkhole susceptibility was improved by using the kernel density function to calculate the nearest sinkhole distance as a continuous variable (Silverman, 1986; Chung, 2006).

One of the most important parts of this methodology is the evaluation of the obtained susceptibility models. Reliable evaluations of models on sinkhole susceptibility are scarce in the international literature (Table 1), and most of the papers do not present information about the reliability of the presented maps, models or methods. Only Galve et al. (2008, 2009b, 2011), Oh \& Lee (2010), Pradhan et al. (2014), D'Angella et al. (2015), Perrin et al. (2015), Ozdemir (2015) and Ciotoli et al. (2016) show reliable validation results. However, the evaluation of models is a common practice in the susceptibility modeling of landslides and earthquakes. Accepted methods to evaluate the capacity of models to forecast the future occurrences of discrete phenomena, such as sinkholes, are described by Chung $\&$ Fabbri (2003) and Begueria
(2006). Among these methods, Receiver Operating Characteristic (ROC) curves and Prediction-Rate Curves (PRCs) are the most widely used techniques (See Table 1). The elaboration of these curves needs the application of cross-validation techniques. Chung $\&$ Fabbri (2003) reviewed diverse options to carry out the cross-validation, and Galve et al. (2009b) applied them to sinkholes affecting the Ebro Valley. We used these techniques to perform a sensitivity analysis for selecting the model that, using the least information, will achieve the highest prediction power.

\section{GEOLOGICAL AND HYDROGEOLOGICAL SETTING}

The evaporites of the Triassic and Permian strata are present in the NW part of FVG, aligned along two clearly defined directions (Venturini et al., 2001; Carulli, 2006). The northernmost alignment is characterized by Late Permian evaporites included in the lower member of the Bellerophon Formation (Fig. 1, blue color) which is typical of the transgressive sequence where the gypsum, characterised by microand saccharoid crystals layered and interbedded with black limestones and dolostones, overlies the continental deposits of the Arenarie della Val Gardena Formation (Upper Permian). The sequence ends with limestone-dolostone-gypsum vacuolar breccias and dolomitic limestones.

Triassic evaporites of the Late Carnian, represented by outcrops of the Raibl Formation, occur in the E-W oriented Tagliamento River Valley (Fig. 1, yellow color). These evaporites, which are deposited in a deep

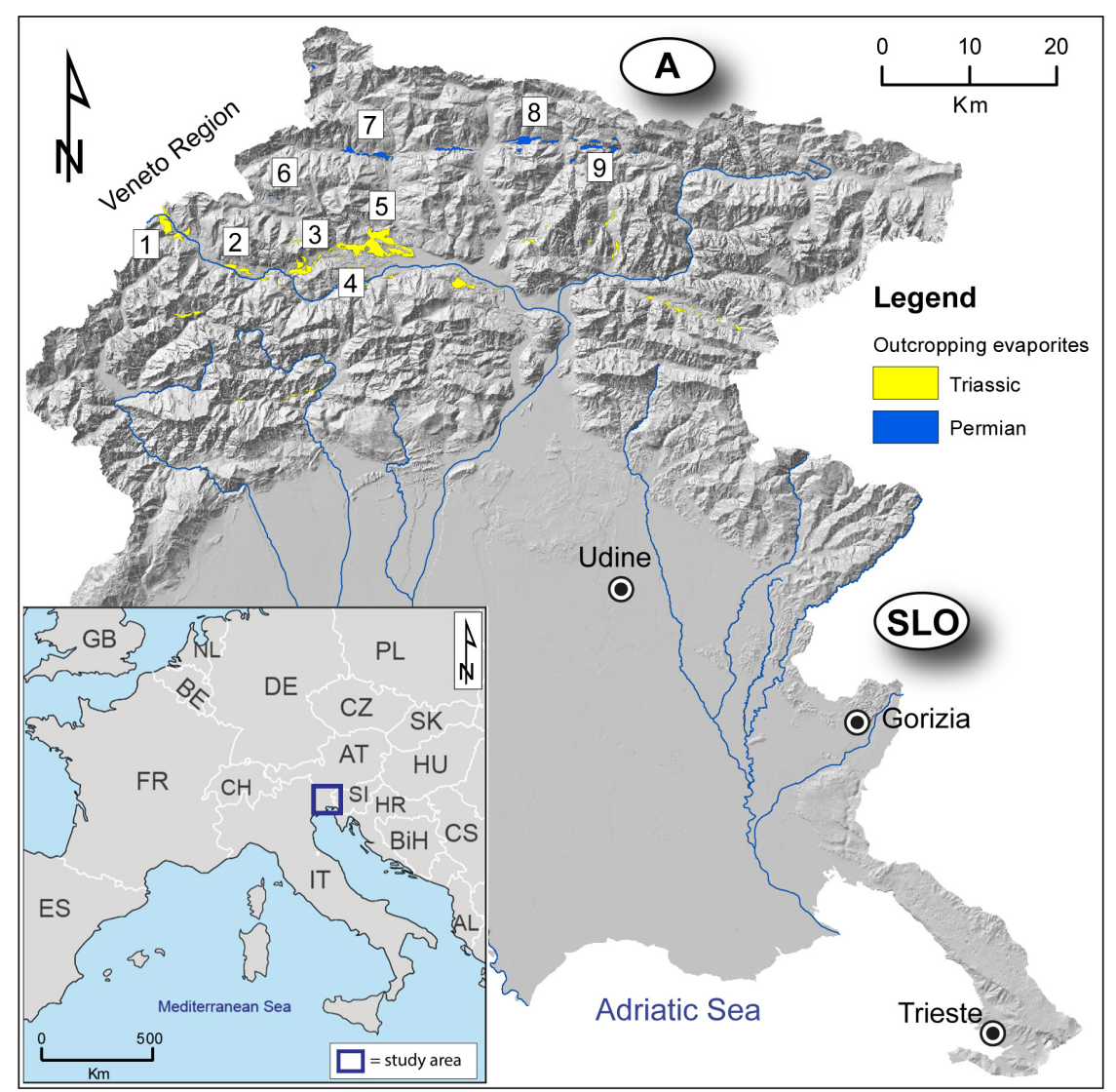

Fig. 1. Location of the study area and the evaporite karst of the Friuli Venezia Giulia region 1) Forni di Sopra; 2) Forni di Sotto; 3) Ampezzo; 4) Socchieve; 5) Enemonzo and Quinis; 6) Sauris; 7) Prato Carnico; 8) Ligosullo; 9) Paularo and its hamlet Dierico. 
lagoon environment, include different lithologies: the red siltstone member with a thickness between 10 and $80 \mathrm{~m}$ at the bottom; the intermediate member of the white and grey saccharoid gypsum, rich in clayey impurities and grey dolomites (thickness of $350 \mathrm{~m}$ ); and the dolomites and marls at the top (thickness of $180 \mathrm{~m}$ ) (Venturini et al., 2001). The Late Carnian evaporites extensively crop out at Enemonzo and Quinis (Venturini et al., 2001; Cucchi \& Piano, 2002; Burelli et al., 2004) (Fig. 2). Their ductile behavior represents a sort of tectonic lubricant for more resistant lithologies.

From a structural viewpoint, the E-W Tagliamento River Valley is controlled by several faults, including the regional Alto Tagliamento overthrust. The latter separates the Carnian Alps (Northern sector) from the Carnian Prealps (Southern sector) (Venturini et al., 2001; Carulli, 2006). In the study area, this structural feature is not detectable at the surface but is buried and recognizable only toward the West, outside the area of interest (Venturini et al., 2001). Furthermore, the study area is characterized by several NW-SE minor faults (Fig. 2).

Evaporites are often capped by recent alluvial deposits, more or less cemented, of the Tagliamento
River or are covered to a less extent by eluvial or colluvial deposits from neighboring reliefs (Fig. 2). Alluvial deposits are heterogeneous in grain size due to the depositional patterns conditioned by the alternation of glacial and interglacial periods, as well as the recent depositional events of the Tagliamento River. For these reasons, the highly permeable polygenic gravels alternate strata of clays and silty-clayey terrains, which decrease the overall permeability (Zini et al., 2015a). In the investigated area, the thickness of the Quaternary deposits increases, from $\mathrm{N}$ to $\mathrm{S}$, ranging from a few meters beneath the foothills to more than $60 \mathrm{~m}$ in correspondence of the Tagliamento floodplain.

The Quaternary deposits are characterized by the presence of an extensive phreatic aquifer which is fed by two contributions: (1) the effective infiltration and the stream leakages in the northern sector; (2) and the Tagliamento river leakages in the southern sector. Water table fluctuations are particularly great and linked to the discharges of the Tagliamento River, which are in turn influenced by the dam activities upstream. During low flow conditions Tagliamento leakages are few with a consequent lowering of the water table. The aquifer is therefore mainly recharged by the stream leakages, which occur in the northern

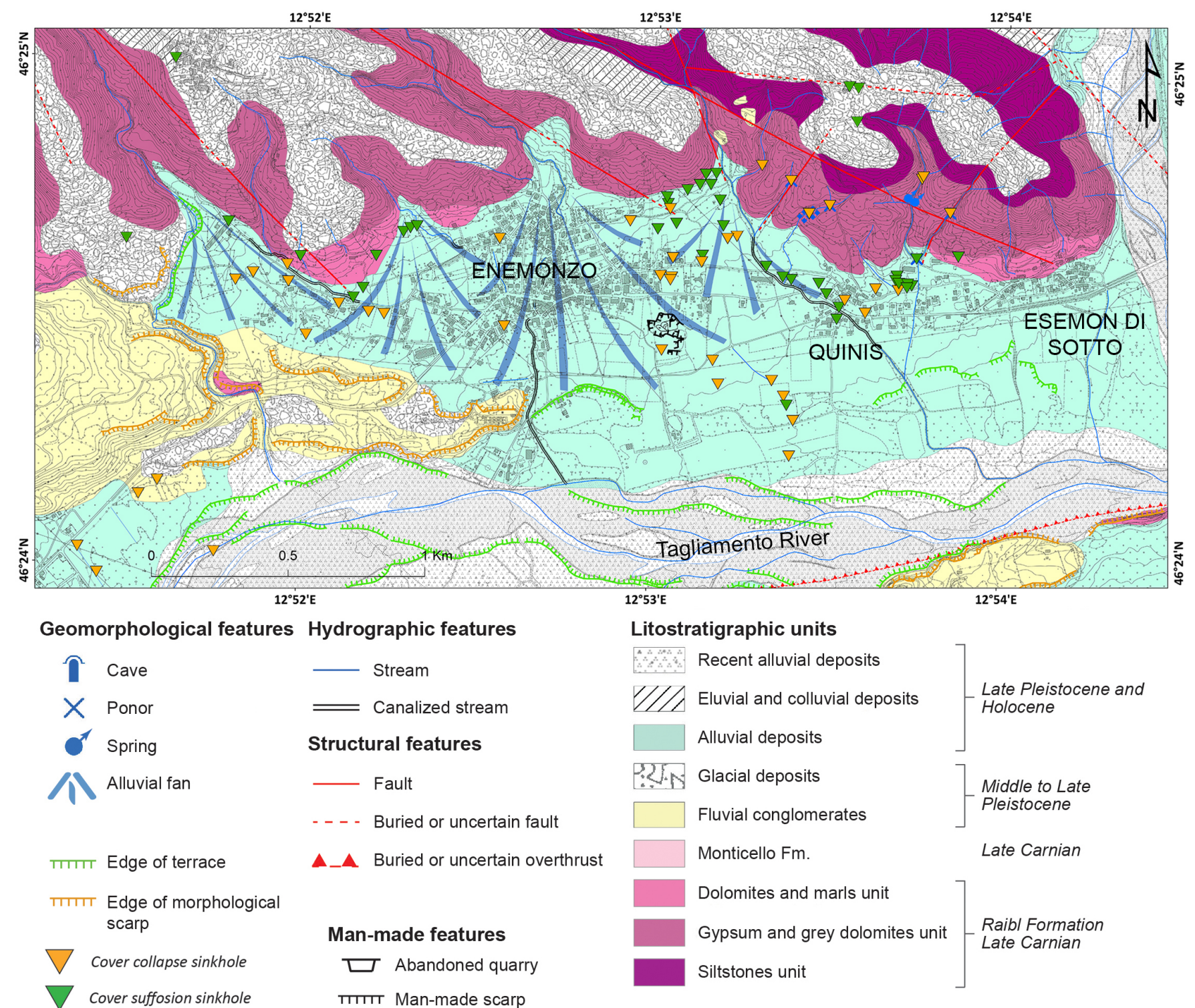

Fig. 2. Geology and geomorphology of the study area. 
sector of the study area. During high flow conditions, the recharge due to the leakages of the Tagliamento River are important and the phreatic levels close to the riverbed and in the inhabited plain areas are comparable. The water table fluctuations reach up to $15 \mathrm{~m}$ with velocities greater than $0.4 \mathrm{~m} / \mathrm{h}$ (recorded in the Quinis area).

\section{MATERIALS AND METHODS}

\section{Sinkhole inventory}

Within the framework of several different projects funded by the Regional Geological Survey of the FVG region as well as by the Enemonzo municipality the researchers of the Mathematics and Geosciences Department of Trieste University realised the first sinkhole inventory of the study area (Calligaris et al., 2017b) (Fig. 3A).

This inventory has been developed through a multiphase approach, which envisaged the following phases: (1) Collection and analysis of documents and reports for the retrospective analysis of sinkhole occurrences; (2) Interpretation of multi-temporal aerial photographs; (3) DTM data analyses; (4) Interviews with locals; and (5) Geomorphological surveying and mapping.

Particular attention was devoted to the retrospective study of sinkhole events that took place during historic times. Bibliographic and archival research has been performed using newspapers and scientific articles and at public institutions. In addition to the historical research, a detailed geomorphological analysis through high resolution DTMs and aerial photographs allowed to recognise the phenomena affecting the study area.

At present 89 sinkholes were identified, 44 of which were classified as cover collapse sinkholes, and 45 as cover suffosion sinkholes, according to the classification of Gutiérrez et al. (2014). The diameters vary between $0.5 \mathrm{~m}$ and $72 \mathrm{~m}$, whereas the depth can reach $15 \mathrm{~m}$. Among the 89 sinkholes, dates of occurrence are available for only a dozen.

In the present section we describe only the known recorded historical events, which represent the meaningful phenomena of the ancient and recent times.

Historical documents report the first sinkhole occurrence in the area since the end of the 1800s (Marinelli, 1898; Zini et al., 2015b, c). In historical pictures taken by locals, a $19^{\text {th }}$ century church located in the center of the Quinis village (Fig. 3E) was restored several times from damage caused by ground subsidence phenomena; the church was demolished in the mid-1970s for safety reasons due to severe damage. An analysis of historical photos indicates that the church was brought down between 1974 and May 1976, when a 6.4M earthquake struck eastern Friuli (Carulli \& Slejko, 2005). The adjacent bell tower still exists, although it is tilted due to the action of underground dissolution processes (Fig. 3E). The above-cited events are probably the best known in $\mathrm{NE}$ Italy related to evaporite subsidence phenomena (De Waele et al., 2017), but the surroundings of Quinis and Enemonzo villages are heavily affected by evaporite dissolution processes. Gortani (1965) reported the occurrence of three significant collapses, one in October 1962 and the other two in October 1964. The first occurred approximately a half $\mathrm{km} \mathrm{S}$ of Quinis, the second formed close by, and the third formed in the Tagliamento riverbed in between Socchieve and Enemonzo villages. Gortani explained that their genesis is attributable to a sudden drop of the groundwater table due to the construction of an upstream hydroelectric plant. The diameters of the above-cited sinkholes were 15,45 , and $25 \mathrm{~m}$, respectively, with maximum depths of 10, 15, and $15 \mathrm{~m}$. Another $10 \mathrm{~m}$ wide subsidence event occurred in 1977 (Fig. 3B) south of Enemonzo in cropland. The sinkhole was immediately filled by locals, but six months later, it was reactivated. In 1985, ten meters away from this last event, a new sinkhole occurred. The local newspapers reported that the depression was approximately $7-8 \mathrm{~m}$ wide and $3.5 \mathrm{~m}$ deep. Three adjacent buildings were demolished, and the rubble was used to fill up the sinkhole. After this event, there was no evidence of new phenomena until 2012, when a new depression, 4 meters in diameter and 2 meters deep, formed (Fig. 3C). Currently, the largest visible sinkhole is located at Molino di Quinis. Its diameter is approximately $15 \mathrm{~m}$, and it is $3 \mathrm{~m}$ deep (Fig. 3D). More recently, in 2013 and 2016, new small-size phenomena occurred.

\section{Conditioning factors}

The identification and construction of a geospatial database of sinkhole conditioning factors play a crucial role in sinkhole susceptibility modelling. However, there are no widely accepted rules for defining a set of sinkhole causal factors. The latter can be different depending on the geological, lithological and hydrogeological characteristics of the study area. Based on the literature (Gortani, 1965), local knowledge, and the outputs of in-depth investigations carried out by Zini et al. (2015a), the following factors have been selected: land use, geomorphology, thickness of the covering deposits, distance to drainage network and distance to faults. Thematic maps representing each factor were produced, and all of the acquired information was stored in a geodatabase.

The land use and geomorphological maps were produced starting from 1:5,000-scale topographical maps, aerial photos and Digital Elevation Models (DEM) at a 1-m resolution, derived from Aerial Laser Scanner (ALS) data acquired in the period from 2006-2010 by the Civil Defence of the Friuli Venezia Giulia Region.

The "land use" (L) factor plays a fundamental role in the sinkhole generation and evolution. Changes in the land use pattern, such as crop variations or the construction of new buildings and roads, modify the infiltration of rainfall into the ground. Floodplain, forest, cropland, grassland and urban areas are the five land use types identified in the study site. The floodplain class includes extensive gravel deposits of Tagliamento riverbed and minor streams. The forest 

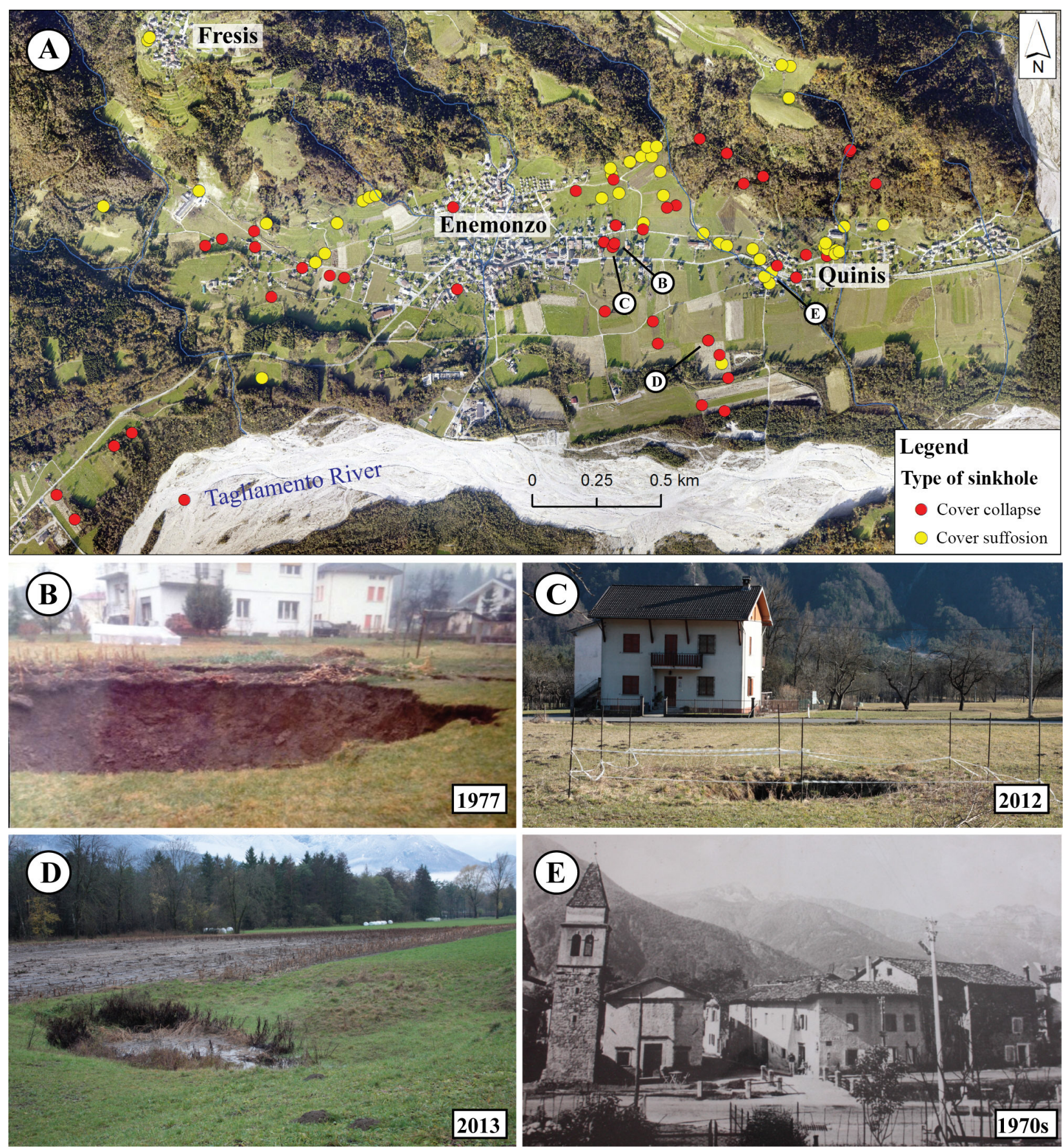

Fig. 3. Sinkhole inventory (A) and field photographs (B, C, D, E) of the types of sinkholes in the study area (DMG, 2015). The phenomena pictured in $B, C, D$, and $E$ are indicated in $A$. B, C, and D are cover collapse sinkholes, while $E$ is a cover suffosion sinkhole.

class incorporates woodlands and land cultivated for afforestation. The cropland class includes field crops and horticulture areas. The grassland class represents areas where the vegetation is dominated by grasses. The urban area unit incorporates transport facilities (roads and car parks), residential and community buildings, industrial areas, quarries and landfill waste disposal sites.

Different areas of land use were recognized using aerial photo interpretation often assisted by field activities. The latter were performed mainly in the surroundings of Quinis and Enemonzo villages, where the definition of limits between different types of land use was frequently complex.

The density and spatial distribution of sinkholes in Friuli Venezia Giulia seems to be dependent on the geomorphological units. The phenomena are more abundant in the flat areas of intra-mountain valleys than at the piedmont hills or along the hillslopes. For the study area, the geomorphological landforms (G) were identified and digitized using aerial photos and validated by field surveys. The area was classified into the following units: riverbed (where water actively flows), floodplain (area of land which experiences flooding during high discharge periods), river terrace, deeply incised stream, hillslope (slopes with angle $>15^{\circ}$ ), fan (fan-shaped deposits of water-transported material (alluvium)), hilltop (flat areas at the top of hill slopes) and cliff (vertical, or nearly vertical, rock exposure).

The definition of the thickness of the Quaternary deposit (T) constitutes a significant factor in the generation and evolution of sinkholes. These deposits are characterised by a high heterogeneity: highly permeable polygenic gravels alternate strata of clays and silty-clayey terrains, which decrease the overall 
permeability. A detailed description of these deposits is given in Zini et al. (2015a) describing the Quinis subsurface deposits. The thickness was calculated from the stratigraphies of 146 boreholes, which are widespread in the study area (data available in the General Municipal Development Plans- PRGCs). Some of them reach the bedrock, whereas others stop in the overlying deposits. The thickness of the Quaternary deposit was ranked into four classes: 0-10 m, 10-20 $\mathrm{m}, 20-40 \mathrm{~m}$, and $>40 \mathrm{~m}$.

Streams and rivers $(\mathrm{H})$ can play an important role in sinkhole generation and evolution. The spatial distribution of streams and rivers shows the areas where the infiltration of shallow waters is concentrated. This factor can be considered an indirect indicator of the dissolution of the evaporites underlying the Quaternary deposits. The Tagliamento River is the major river in Friuli Venezia Giulia Region and flows in a W-E direction in the southern part of the study area. The rest of the drainage pattern is mostly parallel, related to the fact that many streams flow in an approximately NW-SE, structurally controlled direction. We computed the straight-line distance (Euclidean distance) of sinkholes from the rivers.

Evaporite sinkholes are often aligned with geological structures such as faults (F). A map of the faults was constructed using the geological map Carta Geologica delle Alpi Carniche (Foglio occidentale), 1:25,000 scale, from Venturini et al. (2001) and $\mathrm{F}^{\circ} 31$ Ampezzo (Venturini et al., 2010), and then the Euclidean Distance tool was used to compute the required map based on the straight-line distance from the faults.

The elevation (D) and gradient (S) measure the angle of the slopes and control the direction and speed of the runoff waters and erosion of the terrain slopes. For this study, we computed these maps using the Spatial Analyst tool of ArcMap 10.4, produced by ESRI.

For the field survey analyses, the study was realized at a 1:5,000 scale (Calligaris et al., 2017b). The elevation and the products derived from the Digital Elevation Model have a cell size of $1 \mathrm{~m}$.

\section{Susceptibility modelling}

The susceptibility models of the Enemonzo area were constructed using a method based on the Likelihood Ratio ( $\lambda$ ) function (Chung, 2006). This function compares the empirical distributions of the values of a conditioning factor in the pixels with sinkholes and in the pixels without sinkholes. The $\lambda$ function can be expressed by

$$
\lambda(\text { factor })=\frac{f(\text { factor } \mid X\}}{\text { ffactor } \mid \bar{X}\}}
$$

where $f\{$ factor $\mid X\}$ is the empirical distribution function of the values of a factor in the area affected by sinkholes and $f\{$ factor $\mid X\}$ the empirical distribution function of the values of a factor in the area not affected by sinkholes. If these two distributions are very similar, it indicates that the conditioning factor does not explain the distribution of the sinkholes, while if they are very different, this means that the conditioning factor has a high capacity to predict the spatial location of the sinkholes.

The $\lambda$ function can be estimated in each categorical factor $\left(x_{1}, x_{2}, \ldots, x_{i}\right)$ represented in a raster map (i.e., land use or geology) by applying the following equation:

$\check{\Lambda}\left(x_{i}\right)=\frac{\text { Proportion of pixels with sinkhole in the class } x_{i} \text { of the factor } i}{\text { Proportion of pixels without sinkhole in the class } x_{i} \text { of the factor } i}$

The continuous factors are traditionally reclassified into several classes to apply this equation. However, there is another way to estimate $\lambda$ using continuous data by applying a kernel density estimation. A kernel is a smooth function used to spread values of a distribution of numerical data. This function avoids the abrupt jump of frequency values from one range to the next, as can be observed in a conventional histogram formed by block diagrams. We used a normal kernel, namely, a kernel function with a Gaussian distribution, in a shape that has the form:

$$
\mathrm{G}(x)=\frac{1}{\sigma \sqrt{2 \pi}} \mathrm{e}^{-\frac{x^{2}}{2 \sigma^{2}}}
$$

where $\sigma$ is the standard deviation of the distribution. In our case, this kernel function produces a bellshaped curve that describes the distribution of values of a conditioning factor. We generated two kernel density functions for each conditioning factor, which represent the distribution of values in the areas with and without sinkholes. The ratio calculated in each value using the data of these two curves represents the $\lambda$ function of each conditioning factor. This methodology was described in detail by Chung (2006) and applied in sinkhole susceptibility analyses by Galve et al. (2008).

The estimation of $\lambda$ for a set of categorical and continuous factors was performed by multiplying each pixel by the value of $\lambda$ of each factor. See Chung (2006) for a detailed description of the method and Galve et al. (2008, 2009b, 2011) for its implementation to produce sinkhole susceptibility maps.

Additionally, we included the variable Nearest Sinkhole Distance (NSD) in the conventional procedure for estimating $\lambda$ and producing susceptibility maps, as described in Galve et al. (2011). Our innovation is the use of a kernel density function to incorporate in the calculations the NSD as a continuous factor instead of as a categorical factor. First, we carried out a nearest neighbor analysis to calculate the proportion of sinkholes within a given distance from another sinkhole. The results of this calculation are referred to distance ranges and not to continuous distance values. At this point, we estimated the value of this proportion at every distance value by applying a kernel method. We used a normal kernel as in the $\lambda$ estimation for the other conditioning factors. Figure 4 shows the results of this analysis in the Enemonzo area and the Gaussian kernel density function derived from them.

Another factor associated with the sinkhole distribution, the Orientation to Nearest Sinkhole (ONS), has been considered and added to the analysis. 
The generation of a map with this causal factor follows a procedure similar to that used for the NSD. First, the probability of finding another sinkhole following a specific orientation was assessed by observing the frequency of the azimuths of the lines that connect each sinkhole with their nearest neighbors. The result is creating orientation frequencies divided into 16 azimuth ranges of $22.5^{\circ}$. These frequencies $(\mathrm{F})$ were transformed into proportions $(P)$ (Eq. 4), and the proportions were divided by $0.0625(1 / 16)$ to estimate $\lambda$ in each azimuth range.

$$
P=\frac{F}{F_{\text {total }}}
$$

The division by $1 / 16$ has been done because it is assumed that the proportion of pixels in each area covered by the pixels of an azimuth class is the same. Second, an orientation map is produced from the sinkholes and reclassified into 16 classes according to the 16 azimuth ranges of $22.5^{\circ}$. Third, the $\lambda$ value calculated for each azimuth range was assigned to each class of the latter map. This causal factor was shown to be a good predictor in areas where sinkholes show clear lineaments, such as in the Dead Sea sinkhole fields (e.g., Abelson et al., 2006).

\section{Sensitivity analysis through cross- validation techniques}

The prediction capability of the conditioning factors was assessed through the evaluation of the susceptibility models constructed by using each of them or their combinations. This evaluation was carried out through a two-fold cross-validation. Thus, the sinkhole population was divided randomly into two groups, a training dataset and a test dataset. The training dataset was used to produce the susceptibility model, and then this model was evaluated by analyzing the distribution of the sinkholes in the test dataset with respect to the susceptibility values. This evaluation was carried

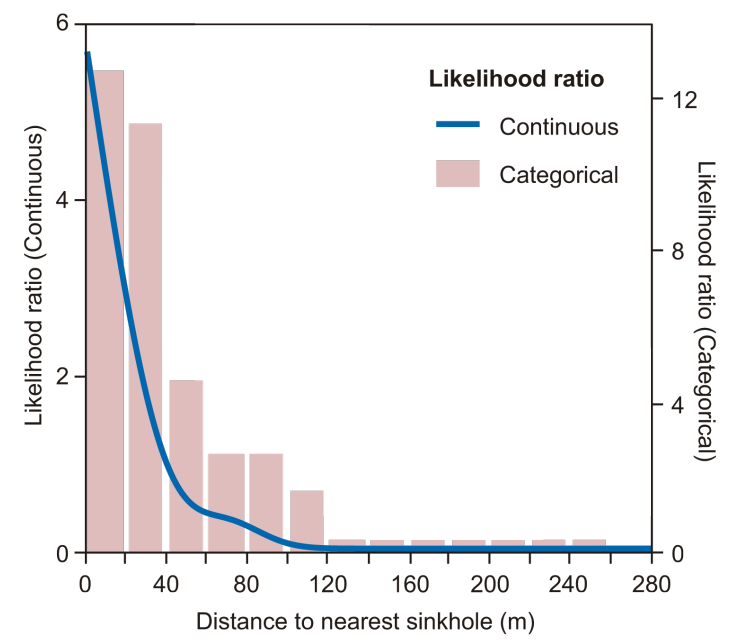

Fig. 4. Likelihood ratio of distance ranges to sinkholes estimated from the observed frequency in each distance range (pink columns; see Galve et al., 2011 for more details about the elaboration of this plot) and empirical frequency distribution of distance to sinkholes using a Gaussian kernel (blue line). out to generate Prediction-Rate Curves (PRCs). These curves graphically show the proportion of the study area, ordered from the highest to the lowest susceptibility, that contain a certain proportion of the test dataset sinkholes (Chung \& Fabbri, 2003; Remondo et al., 2003). Thus, PRCs can be used to obtain information such as the area of the model in which a certain proportion of future sinkholes may occur. For example, we can estimate that a certain percentage of the future sinkholes may occur in a certain percentage of the area with the highest susceptibility. Moreover, the Area Under the Prediction-Rate Curve (AUPRC) was extracted as a quantitative measure of the model forecasting power.

We compared the AUPRCs of the models to identify the factors with the highest prediction capability and the best combination between them for forecasting the locations of future sinkholes (Table 2 and 3). Then, the best model was selected using the following steps: (1) models using only one conditioning factor

Table 2. Prediction capability of variables. AUPRC: Area Under Prediction-rate Curve.

\begin{tabular}{|c|c|c|c|}
\hline ID & VARIABLE & NICKNAME & AUPRC \\
\hline N & Nearest Neighbour Distance & NND & 0.82 \\
\hline L & Land use & LANDUSE & 0.81 \\
\hline G & Geomorphology & GEOMOR & 0.73 \\
\hline T & Thickness of Quaternary deposits & THICKNESS & 0.71 \\
\hline D & Elevation & DEM & 0.71 \\
\hline F & Distance to faults & FAULTDIST & 0.67 \\
\hline S & Slope gradient & SLOPE & 0.64 \\
\hline H & Distance to drainage network & HYDRODIST & 0.58 \\
\hline O & Orientation to Nearest Sinkhole & ONS & 0.45 \\
\hline
\end{tabular}

Table 3. Prediction capability of combinations of the variables in Table 2. The acronyms of the models are produced by combining the IDs of the variables (see Table 2). The PRCs of the combinations highlighted in grey tones are shown in Fig. 5A. VAR: Number of variables combined in the model; AUPRC: Area Under Prediction-rate Curve.

\begin{tabular}{|c|c|c|}
\hline MODEL & VAR & AUPRC \\
\hline NLT $^{*}$ & 3 & 0.885 \\
\hline NLT & 3 & 0.879 \\
\hline NL & 2 & 0.878 \\
\hline NLTD & 4 & 0.873 \\
\hline NLTDF & 5 & 0.870 \\
\hline NLG & 3 & 0.868 \\
\hline NT & 2 & 0.857 \\
\hline $\mathrm{NO}$ & 2 & 0.827 \\
\hline LTDF & 4 & 0.817 \\
\hline LTDHF & 5 & 0.817 \\
\hline LTDH & 4 & 0.811 \\
\hline LTDS & 4 & 0.809 \\
\hline LTD & 3 & 0.809 \\
\hline LGTDFSH & 7 & 0.807 \\
\hline LGTDF & 5 & 0.806 \\
\hline LTF & 3 & 0.803 \\
\hline $\mathrm{LT}$ & 2 & 0.798 \\
\hline LD & 2 & 0.797 \\
\hline LGT & 3 & 0.791 \\
\hline LTH & 3 & 0.788 \\
\hline LG & 2 & 0.777 \\
\hline
\end{tabular}


were evaluated and ordered according to their prediction capability; (2) the combinations of the factors were evaluated from the models combining all the available factors to produce models that combine only the factors with the best performance. We analyzed the trend of the AUPRC value when a factor is included or not. A factor was rejected when the AUPRC did not increase when it was included in the combination. (3) The combination with the highest AUPRC was used to produce a definitive susceptibility map using the entire sinkhole inventory. The contributions of factors when they are incorporated in the analysis can be studied by comparing the spatial patterns of the models and the shapes of the PRCs generated with and without each of the factors (Fig. 5) (see Galve et al., 2009b). This procedure may show how, where and why each factor improves or worsens the model.

\section{RESULTS}

The results of the sensitivity analysis to study the forecasting performance of the selected factors and their combinations are presented in Tables 2 and 3 and Figure 5 . The process produced 32 models, 9 with only one factor and 23 with combinations of different factors. As expected, the variable with the highest prediction capability is the nearest sinkhole distance, followed by land use. The thickness of the covering deposits is the fourth parameter in the ranking of the best-forecast performance, but its addition improved the models more than geomorphology (the third in the ranking).

The sinkhole susceptibility model with the best forecasting performance was produced by combining the following parameters: Nearest Sinkhole Distance (NSD) as a continuous variable, land use and thickness
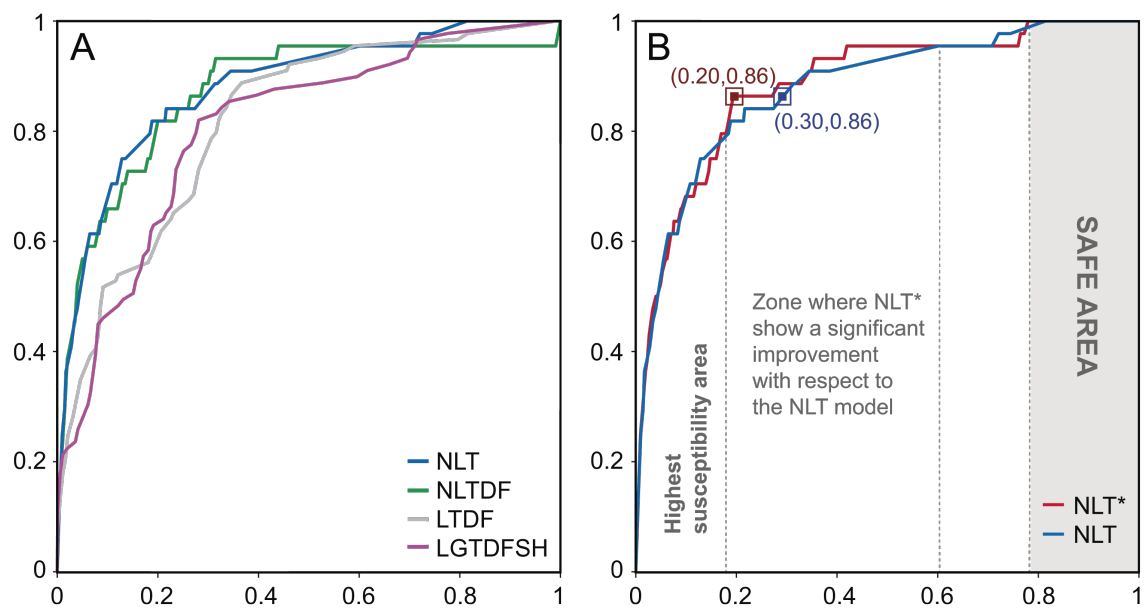

Fig. 5. Prediction-rate curves (PRCs) of the most representative models. Acronyms of the models indicate the combinations of variables (see Tables 2 and 3 for identifying the initial of each variable. (A) PRCs of the combinations that best express the evolution of the prediction capability by adding or subtracting variables from the models. The model LGTDFSH involves all the independent variables, but this combination provides worse results than a model with only four of the parameters (LTDF). The introduction of the N variable (Nearest Sinkhole Distance) improved the latter combination, and this variable with only two additional parameters ultimately generated the best model. (B) Comparison between the PRCs of the NLT model with (NLT*) and without (NLT) the integration of a kernel density estimation. On the one hand, the two combinations indicate an area where the probability of sinkhole occurrence seems to be very low ("safe area") that the other combinations could not define. On the other hand, it is apparent from this plot that $\mathrm{NLT}^{*}$ is better than NLT in almost all the areas of medium susceptibility, and this gives the $\mathrm{NLT}^{*}$ model the highest prediction capability. of the covering deposits (the so-called NLT* model). Only the combination of these three parameters greater predictive power than the combination The NLT* model shows very good performance, with the highest susceptibility (Figs. 5 and 6).

The model with the highest forecast performance was improved by including the parameter NSD as a continuous variable instead of a categorical variable the use of kernel density functions. Although improvement seems to be modest with respect to area with the highest susceptibility. This 5\% $30 \%$ of the study area with the highest susceptibility. As mentioned before, this percentage of sinkholes is predicted by the best model using only $20 \%$ of the study area. Therefore, the "categorical" model needs $\sim 1 \mathrm{~km}^{2}$ more $(\sim 10 \%$ of the study area) to predict the same proportion of sinkholes as the best (Fig. 7)

Orientation to Nearest Sinkhole (ONS) has not dhe improvement generated models is very poor because the sinkholes of the Enemonzo area do not follow clear preferential orientations.

\section{DISCUSSION AND CONCLUSIONS}

The produced susceptibility map highlights the most sinkhole-prone zones of the study area and incorporates the parameters that better represent the conditioning factors that generate and/ or accelerate the sinkhole processes. This map is in a good agreement with the outcomes of the in-depth investigations performed in the past (as the Piano Stralcio per 1'Assetto Idrogeologico P.A.I. Plan, Autorità di Bacino, 2012). Critical points are the area of Esemon di Sotto and the Tagliamento riverbed. In the former area, the susceptibility map classifies the terrain with high and very high susceptibility, although sinkholes have never occurred. A possible explanation for this could be that a strike-slip fault has displaced the evaporites towards the $\mathrm{N}$, leading to the absence of gypsum bedrock in the Esemon di Sotto area. This hypothesis is supported by geological data, as shown in the map proposed by Venturini et al. (2010), but needs to be confirmed 


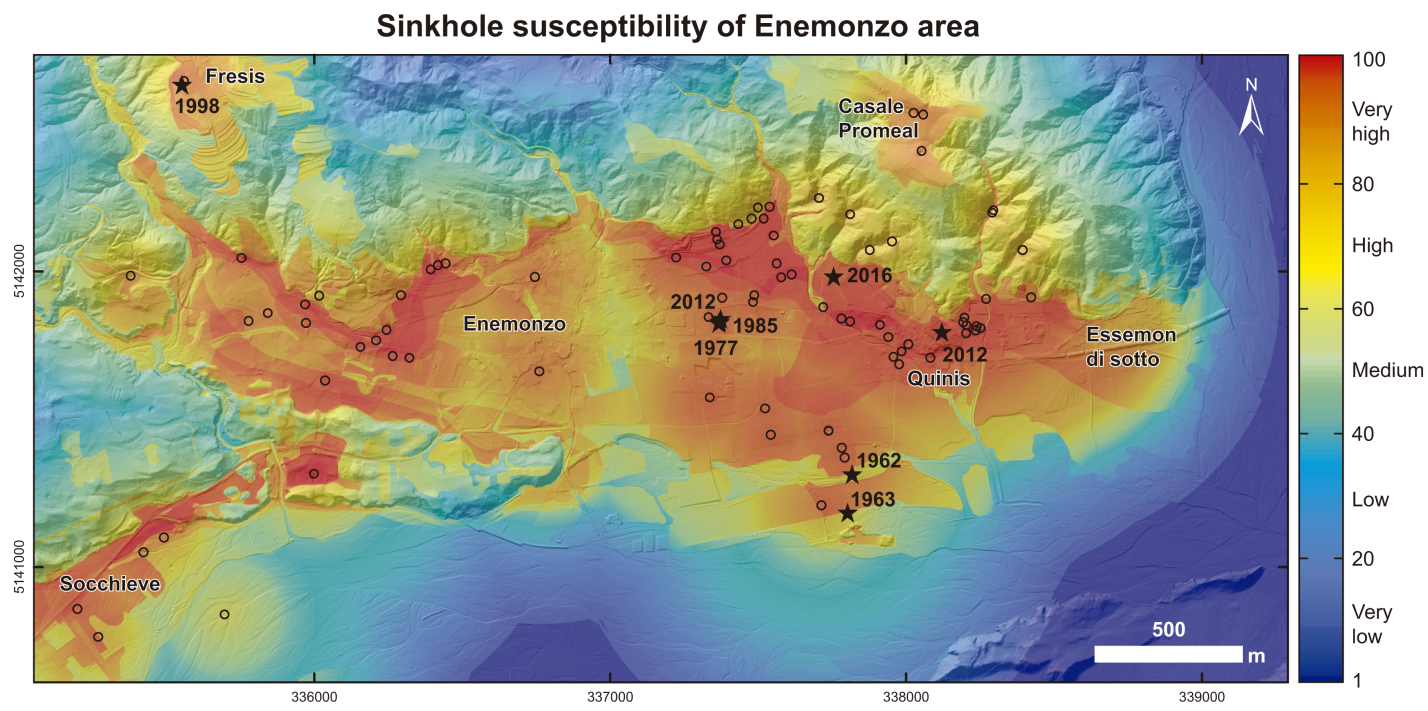

Fig. 6. Sinkhole susceptibility model of Enemonzo area produced using as a training set only the sinkholes without dates (black circles). Dated sinkholes are represented on the model to show the good spatial correlation between the model and their locations (black stars). It is noted that the latter sinkholes were not used in the generation of the model represented in the figure.
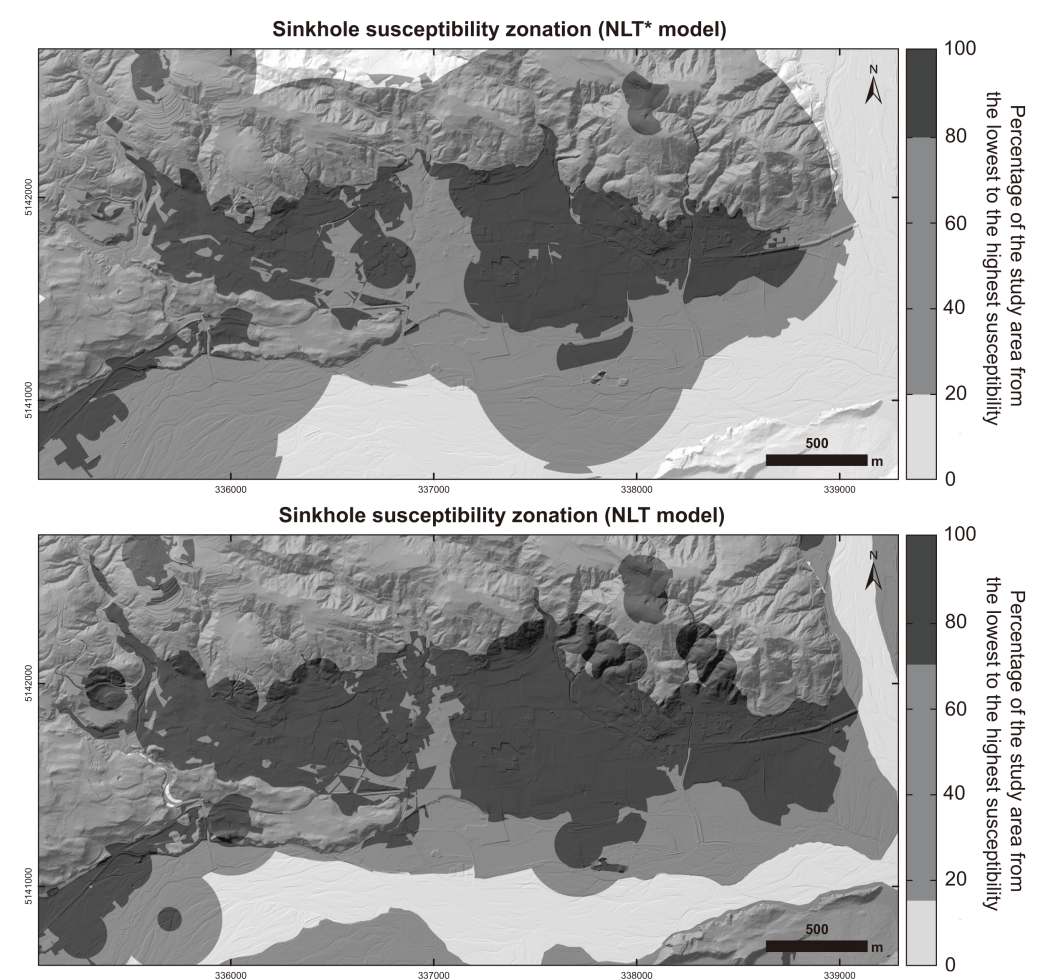

Fig. 7. Sinkhole susceptibility zonation according to the expected percentages of future sinkholes that will occur in each zone. Dark grey zone covers the area where $86 \%$ of future sinkholes will occur, medium grey colored zone covers the area where $14 \%$ of future sinkholes will occur, and the light grey zone covers the so-called "safe area" (see Fig. 4).

by direct investigations. Another critical point is that the Tagliamento riverbed is classified as area of very low or low susceptibility according to the fact that sinkholes were not reported. This might not be realistic. The area is not used for human activities, so witnesses cannot confirm the occurrence of sinkhole phenomena, as fluvial processes can easily hide all the formed karst depressions. To support this hypothesis, Gortani (1965) reported that the variations of the river discharge generated by the upstream construction of a dam caused several subsidence phenomena in the riverbed and in adjacent areas.

The obtained susceptibility map is plausible. The area where Enemonzo Village lies is classified as moderately susceptible. Conversely, the two northern areas of Fresis and Casolare Promeal are classified as very high, in agreement with the sinkholes that occurred in the past. In the central part of the study area, between the villages of Enemonzo and Quinis, sinkholes were not reported in the past. The morphology factor, as well as the great thickness of the deposits (T), seem to have affected the recent formation of sinkholes in this area. Groundwaters follow the bedrock morphology and flow from the northern hills towards the SE depressed areas where sinkholes recently (2012) occurred (Fig. 6).

It is worth noting that in the modelling process, the information provided by the distance to the drainage 
network or faults, geomorphology, elevation and slope was unable to increase the predictive power of the models. The conditions that induce the sinkhole formation at depth do not seem to be reflected at the surface. Most of the aforementioned factors represent characteristics of the landscape and show a limited prediction capacity. It is interesting that the geomorphology factor is the second in the ranking of the best forecasting performance, but its participation in the multivariate models does not improve their prediction power. The geomorphology may affect or be affected by subsidences, but its capacity to predict sinkholes can be included in other factors, such as NSD or land use.

The thickness of the Quaternary deposits is the only variable in our database that represents subsurface information; it shows a moderate capacity to define the most sinkhole-prone areas. This result may be explained by the fact that the available information used to produce the thickness map does not have sufficient detail to generate a significant improvement in the model prediction. However, the slight improvement observed when this factor is included in the model seems to indicate that an upgrading of the thickness estimation would be helpful.

Finally, in the applied methodology, it has not been possible to take into account the role played by the groundwater due to the lack of homogeneous information in most part of the study area. As shown in Quinis where we have an accurate amount of hydrogeological data, the groundwater table fluctuations play a key role in the generation and evolution of ground-subsidence phenomena (Gortani, 1965; Zini et al., 2015a). Unfortunately, there is not enough available information on the water table fluctuation in the rest of the study area.

The discussed topics demonstrate how sinkhole susceptibility modelling outcomes may guide all types of reasoning and conclusions. This paper highlights that the effort of constructing a database and producing and validating a model may provide more than one output: the susceptibility model and the information on how to improve it. The sensitivity analysis indicates which parameters can improve the prediction capability of the best susceptibility model, and thus the analysis process provides us with some direction for further research. In this work, the results indicate that the acquisition of subsurface information and of a continuous inventory of sinkhole occurrences as well as new techniques of analysis may improve the produced model and adapt it to the geological knowledge of the region. In this regard, the susceptibility model should not be seen as a static map, as it evolves as new information is implemented. Seismic risk maps are good examples of that aspect because they are always updated after earthquake occurrences. In Enemonzo, a review of the information used for producing the sinkhole susceptibility model is foreseen. In this sense, (1) the classes of the land use and geomorphology maps must be rethought and (2) the hydrogeological information should be included, as well as new geological subsurface information where it is lacking.

\section{ACKNOWLEDGEMENTS}

The Authors would like to thank the Municipality of Enemonzo and the Geological Survey of the Friuli Venezia Giulia Region, who endorsed the use of the data acquired in the framework of the projects Prot. no. 412/09/11/2011 and Rep. No. 587-15/06/2015. Special thanks go to the locals who provided the historical photos and agreed to be interviewed. J.P. Galve acknowledges funding by the Spanish Ministry of Economy and Competitiveness through the 'Juan de la Cierva' Programme. The authors are grateful to two anonymous reviewers and to G. Ciotoli, K.Z. Doctor and J. De Waele. who enabled a significant improvement in the quality of the manuscript and who re-edited the text.

\section{REFERENCES}

Abelson M., Yechieli Y., Crouvi O., Baer G., Wachs D., Bein A. \& Shtivelman V., 2006 - Evolution of the dead sea sinkholes. Special Paper of the Geological Society of America, 401: 241-253.

https://doi.org/10.1130/2006.2401(16)

Al-Kouri O., Al-Fugara A., Al-Rawashdeh S., Sadoun B. \& Pradhan B., 2013 - Geospatial modeling for sinkholes hazard map based on GIS \& RS data. Journal of Geographic Information System, 5: 584-592.

https://doi.org/10.4236/igis.2013.56055

Autorità di Bacino dei fiumi Isonzo, Tagliamento, Livenza, Piave, Brenta-Bacchiglione, 2012 - Piano stralcio per l'assetto idrogeologico, Carta della pericolosità geologica, Comune di Enemonzo (UD), Tavola 1 di 2. http://pai.adbve.it/PAI_4B_2012/bacino/tagliamento/ pericolosita_geologica/ENEMONZO_1_2.pdf

Begueria S., 2006 - Validation and evaluation of predictive models in hazard assessment and risk management. Natural Hazards, 37 (3): 315-329. https://doi.org/10.1007/s11069-005-5182-6

Bruno E., Calcaterra D. \& Parise M., 2008 - Development and morphometry of sinkholes in coastal plains of Apulia, southern Italy. Preliminary sinkhole susceptibility assessment. Engineering Geology, 99: 198-209. https://doi.org/10.1016/j.enggeo.2007.11.017

Burelli G., Cleva S., Cucchi F. \& Oberti Di Valnera S., 2004 - Stato di evoluzione di sinkholes in alcune aree montane del Friuli Venezia Giulia. In: APAT (Ed.), Stato dell'arte sullo studio dei fenomeni di sinkholes. Proceedings of the $1^{\text {st }}$ Conference, Roma, May 2004, 159-170.

Cahalan M.D., 2015 - Sinkhole formation dynamics and geostatistical-based prediction analysis in a mantled karst terrain. University of Georgia, $64 \mathrm{p}$. https://getd.libs.uga.edu/pdfs/cahalan matthew d 201512 ms.pdf

Calligaris C., Poretti G., Tariq S. \& Melis M.T., 2013 First steps towards a landslide inventory map of the Central Karakorum National Park. European Journal of Remote Sensing, 46: 272-287. https://doi.org/10.5721/EuJRS20134615

Calligaris C., Boschin W., Cucchi F. \& Zini L., 2016 - The karst hydrostructure of the Verzegnis group (NE Italy). Carbonates and Evaporites, 31 (4): 407-420. https://doi.org/10.1007/s13146-016-0320-7

Calligaris C., Devoto S., Zini L. \& Cucchi F., 2017a An integrated approach for investigations of groundsubsidence phenomena in the Ovaro village (NE Italy). In: Renard P. \& Bertrand C. (Eds.), EuroKarst 2016, Advances in Karst Science, Springer, 8: 71-77, Springer International Publishing Switzerland 2017, Neuchâtel. https://doi.org/10.1007/978-3-319-45465-8 8 
Calligaris C., Devoto S. \& Zini L., 2017b - Evaporite sinkholes of the Friuli Venezia Giulia Region (NE Italy). Journal of Maps, 13 (2): 406-414. https://doi.org/10.1080/17445647.2017.1316321

Caporale F., De Venuto G., Leandro G. \& Spilotro G., 2013 - Interventi di mitigazione del rischio da sinkholes nell'area di Lesina marina (Provincia di Foggia, Italia) Sinkhole Mitigation Risk Intervention in the Lesina Marina Area (Province of Foggia, Italy). Memorie Descrittive della Società Geologica d'Italia, 93: 121-142.

Caramanna G., Ciotoli G. \& Nisio S., 2008 - A review of natural sinkhole phenomena in Italian plain areas. Natural Hazards, 45 (2): 145-172.

https://doi.org/10.1007/s11069-007-9165-7

Carulli G.B., 2006 - Carta Geologica del Friuli Venezia Giulia, scala 1:150000. Regione Friuli Venezia Giulia, S.EL.CA. Firenze.

Carulli G.B. \& Slejko D., 2005 - The 1976 Friuli (NE Italy) earthquake. Giornale di Geologia Applicata, 1: 147-156. https://doi.org/10.1474/GGA.2005-01.0-15.0015

Cervi F., Berti M., Borgatti L., Ronchetti F., Manenti F. \& Corsini A., 2010 - Comparing predictive capability of statistical and deterministic methods for landslide susceptibility mapping: A case study in the northern Apennines (Reggio Emilia Province, Italy). Landslides, 7: 433-444.

https://doi.org/10.1007/s10346-010-0207-y

Chung C.J.F., 2006 - Using likelihood ratio functions for modeling the conditional probability of occurrence of future landslides for risk assessment. Computer Geosciences, 32 (8): 1052-1068.

https://doi.org/10.1016/j.cageo.2006.02.003

Chung C. J. F. \& Fabbri A.G., 1993 - The representation of geoscience information for data integration. Nonrenewable Resources, 2 (2): 122-139. https://doi.org/10.1007/BF02272809

Chung C.J.F. \& Fabbri A.G., 2003 - Validation of spatial prediction models for landslide hazard mapping. Natural Hazards, 30 (3): 451-472. https://doi.org/10.1023/B:NHAZ.0000007172.62651.2b

Ciotoli G., Di Loreto E., Finoia M.G., Liperi L., Meloni F., Nisio S. \& Sericola A., 2016 - Sinkhole susceptibility, Lazio Region, central Italy. Journal of Maps, 12 (2): 287-294.

https://doi.org/10.1080/17445647.2015.1014939

Cooper A.H., 1995 - Subsidence hazards due to the dissolution of Permian gypsum in England: investigation and remediation. In: Beck F.B. (Ed.), Karst geohazards: engineering and environmental problems in karst terrane. Proceedings of $5^{\text {th }}$ Multidisciplinary Conference on Sinkholes and the Engineering and Environmental Impacts of Karst Gatlinburg, Tennessee, 2-5 April 1995, A.A.Balkema, Rotterdam, 23-29.

Cooper A.H., Farrant A.R. \& Price S.J., 2011 - The use of karst geomorphology for planning, hazard avoidance and development in Great Britain. Geomorphology, 134 (1-2): 118-131.

https://doi.org/10.1016/j.geomorph.2011.06.004

Cucchi F. \& Piano C., 2002 - Ipercarsismo superficiale e sepolto nelle evaporiti del Friuli-Venezia-Giulia. Le voragini catastrofiche, un nuovo problema per la Toscana, Edizioni Regione Toscana, 35-46.

Dahm T., Kühn D., Ohrnberger M., Kröger J., Wiederhold H., Reuther C.-D., Dehghani A. \& Scherbaum F., 2010 - Combining geophysical data sets to study the dynamics of shallow evaporites in urban environments: application to Hamburg, Germany. Geophysics Journal International, 181: 154-172.

https://doi.org/10.1111/j.1365-246X.2010.04521.x
Dai J., Lei M., Liu W., Tang S. \& Lai S., 2008 - An assessment of karst collapse hazards in Guilin, Guangxi Province, China. Sinkholes and the Engineering and Environmental Impacts of Karst, p. 156-164. https://doi.org/10.1061/41003(327)16

D’Angella A., Canora F. \& Spilotro G., 2015 - Sinkholes susceptibility assessment in urban environment using heuristic, statistical and Artificial Neural Network (ANN) models in evaporite karst system: A case study from Lesina Marina (southern Italy). Engineering Geology for Society and Territory, 5: 411-414. https://doi.org/10.1007/978-3-319-09048-1_79

De Waele J., Piccini L., Columbu A., Madonia G., Vattano M., Calligaris C., D’Angeli I.M., Parise M., Chiesi M., Sivelli M., Vigna B., Zini L., Chiarini V., Sauro F., Drysdale R. \& Forti P., 2017 - Evaporite karst in Italy: a review. International Journal of Speleology, 46 (2): 137-168. https://doi.org/10.5038/1827-806X.46.2.2107 Di Maggio C., Di Trapani F.P., Madonia G., Salvo D. \& Vattano M., 2010 - Primo contributo sui sinkhole nelle evaporiti della Sicilia (Italia)/First report on the sinkhole phenomena in the Sicilian evaporites (Italy). In Proceedings of the 2 Workshop Internazionale. I sinkholes. Gli sprofondamenti catastrofici nell'ambiente naturale ed in quello antropizzato. Roma, 3-4 Dicembre 2009, 299-313.

Doctor K.Z., Doctor D.H., Kronenfeld B., Wong D.W.S. \& Brezinski D.K., 2008 - Predicting sinkhole susceptibility in Frederick Valley, Maryland, using geographically weighted regression. Sinkholes and the Engineering and Environmental Impacts of Karst, p. 243-256.

https://doi.org/10.1061/41003(327)24

Doctor D.H. \& Doctor K.Z., 2012 - Spatial analysis of geologic and hydrologic features relating to sinkhole occurrence in Jefferson County, West Virginia. Carbonates and Evaporites, 27 (2): 143-152. https://doi.org/10.1007/s13146-012-0098-1

Fabbri P., Ortombina M., Piccinini L., Zampieri D. \& Zini L., 2013 - Hydrogeological spring characterization in the Vajont area. Italian Journal of Engineering Geology and Environment, 6: 541-553. https://doi.org/10.4408/IJEGE.2013-06.B-52

Felicísimo Á.M., Cuartero A., Remondo J. \& Quirós E., 2013 - Mapping landslide susceptibility with logistic regression, multiple adaptive regression splines, classification and regression trees, and maximum entropy methods: a comparative study. Landslides, 10 (2): 175-189. https://doi.org/10.1007/s10346-012-0320-1

Forth R.A., Butcher D. \& Senior R., 1999 - Hazard mapping of karst along the coast of the Algarve, Portugal. Engineering Geology, 52 (1-2): 67-74. https://doi.org/10.1016/S0013-7952(98)00056-8

Galve J.P., Remondo J., Bonachea J., Cendrero A, Gutiérrez F., Guerrero J., Lucha P., Gutiérrez M. \& Sánchez J.A., 2008 - Development and validation of sinkhole susceptibility models in mantled karst settings. A case study from the Ebro valley evaporite karst (NE Spain). Engineering Geology, 99 (3-4): 185-197. https://doi.org/10.1016/j.enggeo.2007.11.011

Galve J.P., Gutiérrez F., Lucha P., Guerrero J., Bonachea J., Remondo J. \& Cendrero A., 2009a - Probabilistic sinkhole modelling for hazard assessment. Earth Surface Processes and Landforms, 34 (3): 437-452. https://doi.org/10.1002/esp.1753

Galve J.P., Gutiérrez F., Remondo J., Bonachea J., Lucha P. \& Cendrero A., 2009b - Evaluating and comparing methods of sinkhole susceptibility mapping in the Ebro Valley evaporite karst. Geomorphology, 111: 160-172. https://doi.org/10.1016/j.geomorph.2009.04.017 
Galve J.P., Remondo J. \& Gutiérrez F., 2011 - Improving sinkhole hazard models incorporating magnitudefrequency relationships and nearest neighbor analysis. Geomorphology, 134: 157-170.

https://doi.org/10.1016/j.geomorph.2011.05.020

Gao Y. \& Alexander E.C., 2003 - A mathematical model for a map of the relative sinkhole risk in Fillmore County, Minnesota. Sinkholes and the Engineering and Environmental Impacts of Karst. ASCE, Huntsville, Alabama, 439-449.

https://doi.org/10.1061/40698(2003)39

García-Moreno I. \& Mateos R.M., 2011 - Sinkholes related to discontinuous pumping: susceptibility mapping based on geophysical studies. The case of Crestatx (Majorca, Spain). Environmental Earth Sciences, 64: 523-537. https://doi.org/10.1007/s12665-010-0876-9

Gortani M., 1965 - Le doline alluvionali. Natura e Montagna, 3: 120-128.

Gutiérrez F., Calaforra J.M., Cardona F., Ortí F., Durán J.J. \& Garay P., 2008 - Geological and environmental implications of the evaporite karst in Spain. Environmental Geology, 53 (5): 951-965.

https://doi.org/10.1007/s00254-007-0721-y

Gutiérrez F., Parise M., De Waele J. \& Jourde H., 2014 - A review on natural and human-induced geohazards and impacts in karst. Earth-Science Reviews, 138: 61-88. https://doi.org/10.1016/j.earscirev.2014.08.002

Hyland S., 2005 - Analysis of sinkhole susceptibility and karst distribution in the Northern Shenandoah valley, Virginia: implications for Low Impact Development (LID) site suitability models. Virginia Polytechnic Institute and State University, Blacksburg, Virginia, 56 p. http://scholar.lib.vt.edu/theses/available/etd05232005-081624/.

Iovine G., Parise M. \& Trocino A., 2010 - Instability phenomena in the evaporite karst of Calabria, Southern Italy. Zeitschrift fur Geomorphologie, 54 (2): 153-178. https://doi.org/10.1127/0372-8854/2010/0054S2-0009

Kaufmann O. \& Quinif Y., 2002 - Geohazard map of covercollapse sinkholes in the 'Tournaisis' area, southern Belgium. Engineering Geology, 65 (2-3): 117-124. https://doi.org/10.1016/S0013-7952(01)00118-1

Kaufmann J.E., 2008 - A statistical approach to karst collapse hazard analysis in Missouri. In: Yuhr L.B., Calvin Alexander E., Beck B.F. (Eds.), Sinkholes and the engineering and environmental impacts of karst, 183. ASCE Geotechnical Special Publication, Huntsville, 257-268. https://doi.org/10.1061/41003(327)25

Koutepov V.M., Mironov O.K. \& Tolmachev V.V., 2008 Assessment of suffosion-related hazards in karst areas using GIS technology. Environmental Geology, 54 (5): 957-962. https://doi.org/10.1007/s00254-007-0888-2

Lamelas M.T., Marinoni O., Hopper A. \& de la Riva J., 2008 - Doline probability map using logistic regression and GIS technology in the central Ebro Basin (Spain). Environmental Geology, 54 (5): 963-977. https://doi.org/10.1007/s00254-007-0895-3

Lee S. \& Pradhan B., 2007 - Landslide hazard mapping at Selangor, Malaysia using frequency ratio and logistic regression models. Landslides, 4 (1): 33-41. https://doi.org/10.1007/s10346-006-0047-y

Marinelli O., 1898 - Fenomeni di tipo carsico nei terrazzi alluvionali della Valle del Tagliamento. Memorie della Società Geografica Italiana, 8 (2): 415-419.

Nachbaur A. \& Rohmer J., 2011 - Managing expertinformation uncertainties for assessing collapse susceptibility of abandoned underground structures. Engineering Geology, 123 (3): 166-178. https://doi.org/10.1016/j.enggeo.2011.07.007
Nisio S., Caramanna G. \& Ciotoli G., 2007 - Sinkholes in Italy: First results on the inventory and analysis. In Parise M. and Gunn J. (Eds.), Natural and anthropogenic hazards in karst areas: Recognition, analysis and mitigation. Geological Society Special Publication, 279: 23-45. https://doi.org/10.1144/sp279.4

Oh H.J. \& Lee S., 2010 - Assessment of ground subsidence using GIS and the weight-of-evidence model. Engineering Geology, 115 (1-2): 36-48. https://doi.org/10.1016/j.enggeo.2010.06.015

Ozdemir A., 2015 - Sinkhole susceptibility mapping using Frequency Ratio method and GIS technology near Karapinar, Konya-Turkey. Procedia Earth and Planetary Science, 15: 502-506. https://doi.org/10.1016/j.proeps.2015.08.059

Papadopoulou-Vrynioti K., Bathrellos G.D., Skilodimou H. D., Kaviris G. \& Makropoulos K., 2013 - Karst collapse susceptibility mapping considering peak ground acceleration in a rapidly growing urban area. Engineering Geology, 158: 77-88.

https://doi.org/10.1016/j.enggeo.2013.02.009

Parise M., Qiriazi P. \& Sala S., 2004 - Natural and anthropogenic hazards in karst areas of Albania. Natural Hazards and Earth System Sciences, 4: 569-581.

Parise M. \& Vennari C., 2013 - A chronological catalogue of sinkholes in Italy: the first step toward a real evaluation of the sinkhole hazard. In: Land L., Doctor D.H. \& Stephenson B. (Eds.), Proceedings of the $13^{\text {th }}$ Multidisciplinary Conference on Sinkholes and the Engineering and Environmental Impacts of Karst, Carlsbad (New Mexico, USA), 6-10 May 2013, 383-392.

Paukstys B., Cooper A.H. \& Arustiene J., 1999 - Planning for gypsum geohazards in Lithuania and England. Engineering Geology, 52 (1-2): 93-103.

https://doi.org/10.1016/S0013-7952(98)00061-1

Perrin, J., Cartannaz C., Noury G. \& Vanoudheusden E., 2015 - A multicriteria approach to karst subsidence hazard mapping supported by weights-of-evidence analysis. Engineering Geology, 197: 296-305.

https://doi.org/10.1016/j.enggeo.2015.09.001

Petschko H., Brenning A., Bell R., Goetz J. \& Glade T., 2014 - Assessing the quality of landslide susceptibility maps. Case study Lower Austria. Natural Hazards and Earth System Sciences, 14 (1): 95-118.

https://doi.org/10.5194/nhess-14-95-2014

Piacentini D., Devoto S., Mantovani M., Pasuto A., Prampolini M. \& Soldati M., 2015 - Landslide susceptibility modeling assisted by Persistent Scatterers Interferometry (PSI): an example from the northwestern coast of Malta. Natural Hazards, 78 (1): 681-697. https://doi.org/10.1007/s11069-015-1740-8

Pradhan B., Abokharima M.H., Jebur M.N. \& Tehrany M.S., 2014 - Land subsidence susceptibility mapping at Kinta Valley (Malaysia) using the evidential belief function model in GIS. Natural Hazards, 73 (2): 10191042. https://doi.org/10.1007/s11069-014-1128-1

Remondo J., González A., Diaz de Terán J.R., Cendrero A., Fabbri A. \& Chung C.J.F., 2003 - Validation of landslide susceptibility maps; examples and applications from a case study in northern Spain. Natural Hazards, 30 (3): 437-449.

https://doi.org/10.1023/B:NHAZ.0000007201.80743.fC

Samyn K., Mathieu F., Bitri A., Nachbauer A. \& Closset L., 2014 - Integrated geo- physical approach in assessing karst presence and sinkhole susceptibility along floodprotection dykes of the Loire River, Orleans, France. Engineering Geology, 183: 170-184. 
Silverman B.W., 1986 - Density estimation for statistics and data analysis. New York: Chapman and Hall.

Simón J.L. \& Soriano M.A., 2002 - Actual and potential doline subsidence hazard mapping: case study in the Ebro basin (Spain). In: Bobrowsky P.T. (Ed.), Geoenvironmental Mapping: Method, Theory and Practice. Balkema, Rotterdam, 649-666.

Simón J.L., Soriano M.A., Gracia J. \& Salvador T., 1991 - Dolinas aluviales en las terrazas del Ebro al oeste de Zaragoza: un análisis empírico de los factores de riesgo. Cuaternario y Geomorfología, 5: 139-148. http://tierra.rediris.es/CuaternarioyGeomorfologia/ images/vol5/cuaternario5(1-4) 12-.pdf

Soriano M.A. \& Simón J.L., 1995 - Alluvial dolines in the central Ebro basin, Spain: a spatial and development hazard analysis. Geomorphology, 11 (4): 295-309. https://doi.org/10.1016/0169-555X(94)00066-Z

Steger S., Brenning A., Bell R., Petschko H. \& Glade T., 2016 - Exploring discrepancies between qualitative validation results and the geomorphic plausibility of statistical landslide susceptibility maps. Geomorphology, 262: 8-23. https://doi.org/10.1016/j.geomorph.2016.03.015

Taheri K., Gutiérrez F., Mohseni H., Raeisi E. \& Taheri M., 2015 - Sinkhole susceptibility mapping using the analytical hierarchy process (AHP) and magnitudefrequency relationships: A case study in Hamadan province, Iran. Geomorphology, 234: 64-79. https://doi.org/10.1016/j.geomorph.2015.01.005

Thierry P., Prunier-Leparmentier A.M., Lembezat C., Vanoudheusden E. \& Vernoux J.F., 2009 - 3D geological modelling at urban scale and mapping of ground movement susceptibility from gypsum dissolution: The Paris example (France). Engineering Geology, 105 (1-2): 51-64.

https://doi.org/10.1016/j.enggeo.2008.12.010

Venturini C., Pondrelli M., Fontana C., Delzotto S. \& Discenza K., 2001 - Carta Geologica delle Alpi Carniche, Foglio Occidentale, scala 1:25000. Museo Friulano di Storia Naturale, S.EL.CA. Firenze.
Venturini C., Delzotto S., Pondrelli M., Fontana C., Pondrelli M., Longo Salvador G., Carulli G.B. \& Pisa G., 2010 - $\mathrm{F}^{\circ} .031$ Ampezzo (Carta geologica d'Italia alla scala 1:50.000). ISPRA - Servizio Geologico Nazionale.

Wu Y.P., Wei J. \& Hui Y., 2010 - Karst collapse hazard assessment system of Wuhan city based on GIS. In: 2010 International Symposium in Pacific Rim, Taipei, Taiwan, April 2010, p. 26-30.

Yilmaz I., 2007 - GIS based susceptibility mapping of karst depression in gypsum: A case study from Sivas basin (Turkey). Engineering Geology, 90 (1-2): 89-103. https://doi.org/10.1016/j.enggeo.2006.12.004

Zini L., Calligaris C. \& Zavagno E., 2014 - Classical Karst hydrodynamics: a sheared aquifer within Italy and Slovenia. In: Evolving water resources systems: Understanding, predicting and managing water-society interactions. IAHS Publication, 364: 499-504. https://doi.org/10.5194/piahs-364-499-2014

Zini L., Calligaris C., Forte E., Petronio L., Zavagno E., Boccali C. \& Cucchi F., 2015a - A multidisciplinary approach in sinkhole analysis: the Quinis village case study (NE-Italy). Engineering Geology. 197: 132-144. https://doi.org/10.1016/j.enggeo.2015.07.004

Zini L., Casagrande G., Calligaris C., Cucchi F., Manca P., Treu F., Zavagno E. \& Biolchi S., 2015b - The Karst hydrostructure of the Mount Canin (Julian Alps, Italy and Slovenia). In: Andreo B., Carrasco F., Durán J.J., Jiménez P., LaMoreaux J. (Eds.), Hydrogeological and environmental investigations in karst systems. Environmental Earth Sciences, 1: 219-226. https://doi.org/10.1007/978-3-642-17435-3 24

Zini L., Calligaris C. \& Cucchi F., 2015c - The challenge of tunneling through Mediterranean karst aquifers: the case study of Trieste (Italy). Environmental Earth Sciences, 74 (1): 281-295. https://doi.org/10.1007/s12665-015-4165-5

Zisman E.D., 2001 - A standard method for sinkhole detection in the Tampa, Florida, area. Environmental \& Engineering Geoscience, 7 (1): 31-50. https://doi.org/10.2113/gseegeosci.7.1.31 